\title{
Implementing Plan-Do-See Model to Improve Quality of Biology Learning Process at Senior High Schools in Aceh
}

\author{
Djufri \\ Universitas Syiah Kuala \\ Banda Aceh, Indonesia \\ djufri_bio@yahoo.com
}

\author{
Melvina \\ Universitas Syiah Kuala \\ Banda Aceh, Indonesia
}

\begin{abstract}
Regarding survey towards National Examination or UN at 12 areas in Aceh Province through Mapping Research and Education Quality Improvement (PPMP) program that was conducted in 2011, indicated students low achievement on several standards and basic competencies in biology subject. Then, PlanDo-See model is implemented to overcome lacking standard and basic competencies by improving biology learning process. This implementation purposes to measure the effectivity of model implementation that results in an increase in basic and standard competencies towards students in Aceh province. The model is divided by stages: (Plan) teachers sit into groups and develop learning instrument especially lesson plan together; (Do) a teacher is selected to be a model teacher while other members of the group acted as an observer; (See) give reflection to model teacher to improve learning quality. In general, Plan-Do-See model improves teachers' abilities in planning and implementing biology learning, as well able to improve implementation where the effectivity of the model implementation is measured by achievement level of teachers' and students' competencies towards problematic basic and standard competences in biology subject.
\end{abstract}

Keywords-Plan-Do-See Model, Biology learning; Competence Standard; Basic Competence; Model implementation component

\section{INTRODUCTION}

According to PM-PMP research [1], that was conducted at 3 schools at every district of Aceh province in 2011 found several problems related to learning quality, where the samples schools. The problems are:

- Teachers low comprehension on content especially at certain difficult basic competence, so it affects students' comprehension

- Teachers are not able to motivate students well so it results in students' low learning motivation.

- Low students' motivation in learning influence UN score. Most teachers teach in the traditional way, mostly is preaching.

- Lacking facilities and usage of laboratories for subjects like Biology, Chemistry, and Physics.

- Students are careless in doing exam because they don't read the question carefully and are not able to understand/analyze question well

- Not all lesson plan is developed by teachers
- Indicators that are developed by teachers cover the low level of thinking of cognitive domain like knowledge, comprehension, and application $(\mathrm{C} 1, \mathrm{C} 2$, and $\mathrm{C} 3)$ while the levels of UN item questions are range from $\mathrm{C} 1$ until C6.

- Lacking Media usage that is planned by teacher

- Some teachers still skip difficult topics

- Most teachers are lacking IT skill, so it effects on lacking references used by the teacher.

- The school environment is not well managed, it effects learning the culture.

- Lacking parents' attention to their children except for close to UN time.

- School committee doesn't function at optimum.

To solve the problems then was conducted PM-PMP Service in 2012 at the same targeted schools.

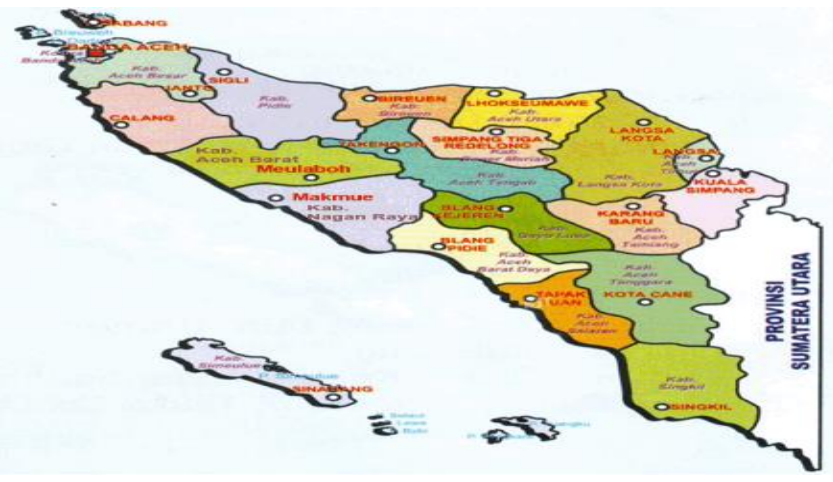

Fig. 1. Map of PM-PMP Service in Aceh Province.

Referring to National Exam report, Aceh education quality on every level is still lower than other provinces in Indonesia. Student comprehension in biology subject at every competence in biology is not distributed equally or variation. Students comprehension on every subject is under $45 \%$, even where the level of student's comprehension is under $15 \%$ on $3-5$ competence. The differences in comprehension level cause the average achievement of UN score at every subject is not maximum.

There are several indications that cause national standard cannot be reached: 1) low comprehension on content 
curriculum; 2) low comprehension on subject matter, especially biology subject; 3) lacking biology teacher's pedagogical knowledge ; 4) lacking facilities and infrastructures; 4) unconducive learning culture; and 5) low-level capability in managing school. The mentioned factors affect negatively students' comprehension on learning material and National Examination.

The expected outcome for this service are: 1) Teachers' comprehension on content and process standard increase until $>75 \%$; 2) Teachers' skills in developing learning instrument are improved, indicated in form of lesson plan 3) Teachers' skills in implementing instruction based on lesson plan meet the content and process standard.

\section{METHODS}

Regarding the findings that cause low UN score for Biology at SMA in Aceh Province in the last three years (3), then formulated a model to overcome this problem. Then is implemented Plan-Do-See Model. The principle of Plan-DoSee Model is adapted and developed from Lesson study. Lesson study is firstly developed in Japan. Nowadays, is starting introduced in many international forum [2] aim to improve qualities of teacher teaching and teachers professional capacities through peer review on daily basis [3].
Basically, Lesson Study is real collaboration among teachers to improve instruction quality [2], follows Plan-DoSee model. In this model applies the collaborative principle in form of research about learning quality performance by the teacher, so lesson study can be conducted by teachers as research media to achieve learning objective and improve learning quality. The stages are applied in lesson study follow 3 main stages namely Plan-Do-See, aims to improve learning quality:

- Plan (Developing Lesson Plan): assisting teachers in developing learning instrument namely: syllabus development, lesson plan, rubric assessment, student worksheet, learning material, and learning media

- Do (Implementing and Observing Learning Implementation): teaching implementation based on planned learning instrument by selecting teacher model, while other teachers and lecturer supervisors acted as observers.

- See (Reflecting Learning Implementation): based on observation result then is continued by reflection and discussion about teaching performance, what should be fixed at next lesson. The discussion is more focus on student's behavior in the classroom during observation. It is expected that teacher can reflect themselves through the reflection of observers towards students' behaviors.
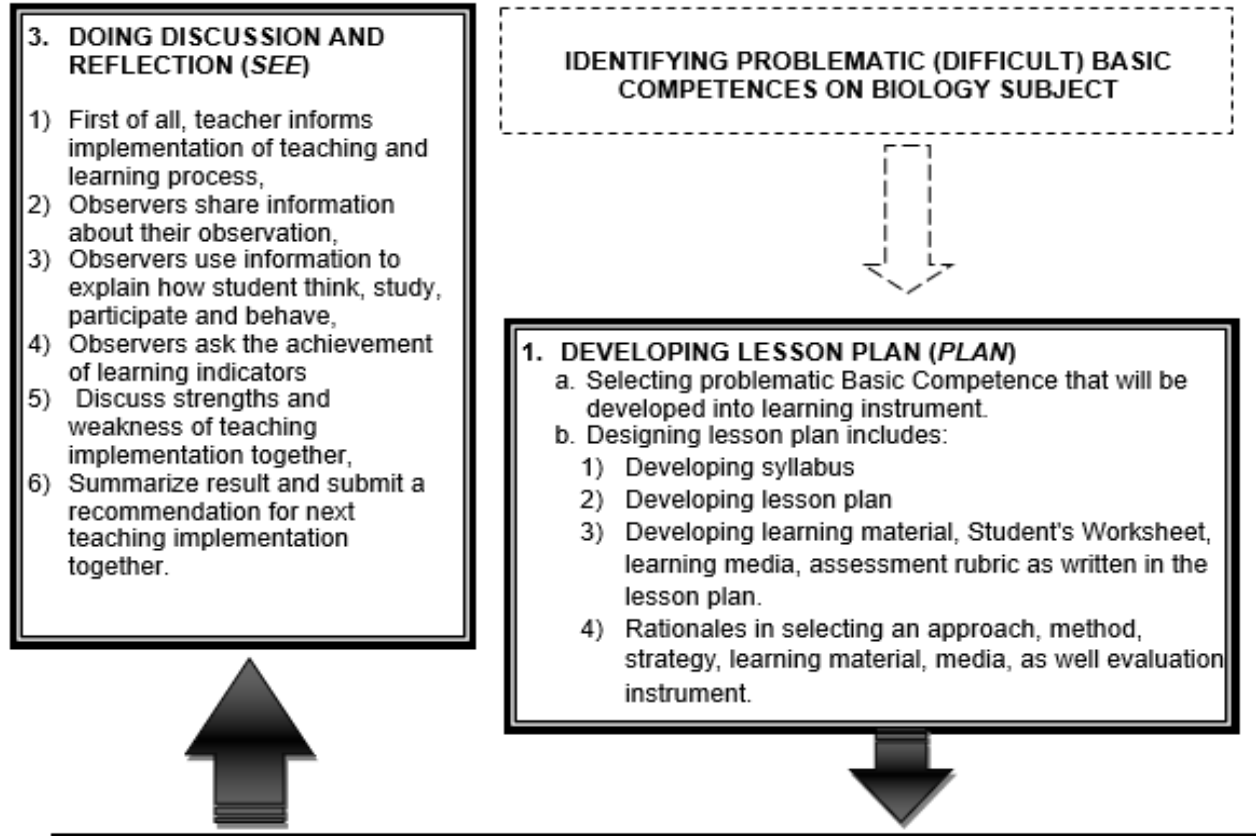

2. IMPLEMENTING AND OBSERVING LEARNING $(D O)$

1) A model teacher performs teaching according to a lesson plan that had been planned together.

2) Other teachers from the same subject as well lecturer supervisor observe and collect information related to students activities in the classroom (thinking, studying, participating, and

Fig. 2. Low Chart of Plan-Do-See Model Implementation 


\section{RESULTS AND DISCUSSIONS}

\section{A. Plan (Developing Lesson Plan)}

In this stage, lecturer supervisors assist chemistry high school teachers in developing learning instrument such syllabus development, lesson plan, rubric assessment, student worksheet, learning material, and learning media. There are about 125 biology high school teachers who joint this service that covers 23 districts/cities at 12 areas in Aceh province. Each city or district there are about 6 teachers and assisted by one or two lecturer supervisors.

In order to improve teachers' comprehension on problematic Basic Competencies, teachers develop learning instrument together on difficult Basic Competence. A number of problematic basic competence is varied in every area, but in South East district and Gayo Lues district covers 17-19 basic competencies that are considered problematic. Furthermore, topics of problematic basic competencies are varied in every area. The following are topics considered difficult/problematic basic competence by teachers:

- Plant Physiology (photosynthesis and respiration)

- Genetic (Kreb's cycle and probability theory)

- Biodiversity (species, population, and community)

- Microbiology (Bacteria, Fungi, and Lichens)

\section{- Food Chain and Web Chain}

Teachers develop learning instrument collaboratively assisted by lecturer supervisor to produce standard lesson plan. Mostly lesson plans that are developed by teachers integrated innovative and student-centered approaches. The integrated learning models like collaborative, cooperative model and learning methods like an experiment, discussion, asking and answer and lesson study model. According to questionnaire > $70 \%$ teachers experience increase in the basic competence through developing qualified learning instrument, especially lesson plan indicated by learning an instrument that had been produced. The produce lesson plan in categorized as good at level (71-84) and meet the standard. In addition, > 75\% teachers experience increase comprehension on problematic Basic Competence during collaborative work in Planning learning instrument.

\section{B. Do (Implementing and Observing Learning Implementation)}

At Plan stage, teacher produced 2-3 lesson plans varied in every area. The lesson plans, they are corrected by lecturer supervisor. Then, a lesson plan that is considered the best selected to be implemented in teaching. In this stage, a teacher is selected as teacher model while other teachers and lecturer supervisor acted as observers. The observation is focused on what happens during the learning process and focus on students behavior in the classroom rather than judging teacher's teaching performance.

In general, > 90\% teacher models are able to implement teaching according to lesson plan, and experience improvement in teaching skill that is indicated by students behaviors as follow:

- Learning is centered on students

- Students are more active

- Students are motivated to present the best during group discussion

- Most students have actively participated in group discussion

- Designed lesson plan is engaged students' attention

- Learning models and approaches are implemented well and suitable with a learning objective.

- Teachers' comprehension of learning material is good

- Given evaluation by teacher is suitable with determined indicators

- Teachers do reflection and follow up action suitable with the lesson plan.

\section{See (Reflecting Learning Implementation)}

In See stage, observation result provided from Do stage is reflected and discussed together. Teacher models reflect what should be fixed from students' behaviors during the learning process. Teacher models improve content comprehension > $85 \%$. The following are the general reflection provided from See stage:

- Teachers model felt nervous during observation because they are not familiar with lesson study.

- Teacher models get constructive inputs and feedbacks from teachers observers and lecturer supervisors.

- All teacher that are involved this service activity motivated to apply what they had learnt during this activity to their class.

- All teachers and lecturer supervisors do reflection about class management, student's miss-attitude and discuss strategies to overcome the problems.

\section{CONCLUSIONS}

Aligned to outcome expected by this service, it can be concluded that:

- Teachers' comprehension on content and process standard increase, it is indicated by $>70 \%$ teachers experience increase comprehension on problematic Basic Competence during collaborative work in Planning learning instrument

- Teachers' skill in developing learning instrument is improved where $>75 \%$ teachers experience increase competence in developing qualified to learn instrument where lesson plan in categorized as good at level (71-84) and meet the standard

- Teachers skill in implementing instruction based on lesson plan based on content and process standard is 
indicated by $>90 \%$ teacher models are able to implement teaching according to the lesson plan.

- Teachers get constructive inputs and feedbacks from reflection and motivated to improve their teaching in the field by applying what they had learnt from this service activity.

\section{SUGGESTIONS}

- Chemistry Teachers should adopt Plan-Do-See model to improve their teaching qualities by working collaboratively with other teachers.

- Education Office at Provincial or District level should consider Plan-Do-See model of lesson study should be an alternative to solving learning problem in Biology subject, especially increase student's UN score.
- $\quad$ FKIP Syiah Kuala University should continue this service activity to all education level to improve learning qualities in the field.

\section{REFERENCES}

[1] Djufri, Rajab Bahry, and Mukhlis Hidayat 2013. Implementation of WTO Model to Improve Quality of Senior High Schools in South East Aceh and Gayo Lues of Aceh Province. Proceedings: International Conference on Special Education. Teacher Training and Education Faculty, Syiah Kuala University, Indonesia.

[2] Fernandez, C. 2002. Learning from Japanese Approaches to Professional Development: The Case of Lesson Study, Journal of Teacher Education 2002; 53; 393; DOI: 10.1177/002248702237394 (accessed 13-7-2012).

[3] Baba, T. And Kajima, M. 2003. Lesson Study. Japan International Cooperation Agency (ed) Japanese Educational Experiences. Tokyo: Japan International Cooperation Agency. 